\title{
Isolation and purification of human large bowel mucosal lymphoid cells: effect of separation technique on functional characteristics
}

\author{
P. W. BLAND, E. R. RICHENS, D. C. BRITTON, AND J. V. LLOYD \\ From the Department of Clinical Investigation, Royal United Hospital, Bath, and the Pharmacology Group, \\ University of Bath, Bath
}

SUMMARY Human large bowel lamina propria lymphoid cells have been isolated using both mechanical and enzymatic techniques. Their separation from other cell types after isolation was effected with greater efficiency by sedimentation on isokinetic gradients than by filtration through glass bead columns. After being purified, the capacity of the lamina propria lymphocytes to function in vitro as effector cells in antibody-dependent cellular cytotoxicity was determined. Mechanical disruption of the mucosa gave low yields of lymphoid cells, which lacked the capacity for cytotoxicity. Enzymatic digestion of mucosal tissue, by comparison, yielded large numbers of viable lymphoid cells which retained a significant level of cytotoxic activity. Investigation revealed that mechanical homogenisation stimulated the synthesis of prostaglandin $E_{2}$, and inhibitor studies showed that this mediator was responsible for the lack of cytotoxic activity in mechanically-liberated lymphocytes.

The assessment of peripheral immunological parameters in intestinal diseases may reveal little in relation to events occurring at the site of the mucosal lesion and, consequently, little in relation to possible immune aetiology of the disease. It is possible, for example, that the contradictory reports concerning an anergy in cell-mediated immunity in Crohn's disease (Verrier-Jones et al., 1969; Richens et al., 1974; Meuwissen et al., 1975; Meyers et al., 1976; MacPherson et al., 1976; Auer et al., 1978a,b) result from an ignorance of simultaneous mucosal immunological status. Ideally, mucosal and peripheral immune competence should be assayed simultaneously. The development of techniques separating high yields of viable lymphocytes from human intestinal mucosa is, therefore, of great importance.

Such procedures have been described, using either mechanical methods (Breucha et al., 1974a,b; Mavligit et al., 1974; Rudzik and Bienenstock, 1974; Clancy, 1976; Goodacre et al., 1979) or enzymatic methods (Bull and Bookman, 1977; Arnaud-Battandier et al., 1978; Crofton et al., 1978) to disrupt the mucosal tissue. It is important that these two categories of technique should be com-

Received for publication 18 July 1979 pared, not only in terms of efficiency-that is, numbers of lymphoid cells recovered-but also in terms of lymphoid cell function after separation.

This report describes the use of a mechanical method and an enzymatic method for the separation of human large bowel lamina propria lymphoid cells, and also two techniques for their subsequent purification. The ability of the recovered lymphoid cells to function in in vitro cytotoxicity reactions has also been assessed.

\section{Methods}

MEDIA

Eagle's Minimum Essential Medium (EMEM) and calcium- and magnesium-free Eagle's Minimum Essential Medium (MEMS) were obtained as $10 \times$ concentrates from Flow Laboratories, Irvine, Scotland, and were routinely supplemented at single strength with the following: $10 \%$ foetal calf serum (FCS, Flow Laboratories), previously heatinactivated for 30 minutes at $56^{\circ} \mathrm{C}$ (except Chang cell culture, see below); $20 \mathrm{mM}$ HEPES; $4.5 \mathrm{mM}$ sodium bicarbonate; $2 \mathrm{mM}$ L-glutamine; $40 \mu \mathrm{g} / \mathrm{ml}$ gentamicin and $0 \cdot 125 \mu \mathrm{g} / \mathrm{ml}$ amphotericin B (Fungizone, Squibb). Phosphate buffered saline (PBS) was used without additives and calcium- and 
magnesium-free PBS (PBSA, Dulbecco 'A', Oxoid) was supplemented as shown in the text.

\section{TISSUES}

Specimens of colon or rectum were obtained at operation from patients undergoing surgical resection for Crohn's disease (CD) or adenocarcinoma of the large intestine (AC). Only macroscopically normal tissue at least $40 \mathrm{~mm}$ from the edge of any inflammatory or neoplastic lesion was used. Tissues were placed in ice-cold MEMS immediately after resection and separation procedures were initiated within 30 minutes.

\section{LIBERATION OF LAMINA PROPRIA}

LYMPHOID CELLS

Plastic petri dishes and tubes (Sterilin) or siliconised glassware were used throughout all cell-handling procedures.

\section{Mechanical method}

Approximately $5 \mathrm{~g}$ of mucosa was carefully dissected free of all underlying submucosal and muscle tissue and was washed extensively in MEMS to remove surface debris. The mucosal tissue was then finely minced with scissors into pieces measuring approximately $1-2 \mathrm{~mm}^{2}$ and homogenised in a glass/Teflon tissue homogeniser (tolerance approximately $\mathbf{0 . 0 3 0}$ in). The homogenate was then forced through a stainless steel grid (mesh size, $0.5 \mathrm{~mm}$ ) using a rubber policeman and through $19 \mathrm{G}$, then $21 \mathrm{G}$ hypodermic needles to further disrupt tissue masses. Mucus was removed from the resulting suspension using the method of Clancy (1976); the suspension was shaken on a vortex mixer (Griffin), centrifuged at $400 \mathrm{~g}$ for five minutes, and the supernatant containing disrupted mucus discarded; the cell pellet was resuspended in MEMS and the process was repeated six times. At this stage the supernatant appeared to be clear of mucus, although microscopically the cells, when resuspended, still showed clumping in mucus remnants to a variable degree. These cell clumps were further disaggregated by filtration of the suspension through two successive columns constructed from $10 \mathrm{ml}$ plastic syringe barrels, each loosely packed with $5 \mathrm{ml}$ nylon wool, which were subsequently flushed with $2 \times 10 \mathrm{ml}$ MEMS. The resultant suspension of lymphoid, epithelial, and other cell types was then purified using either columns of siliconised glass beads or isokinetic gradients of Ficoll in MEMS, as described below.

\section{Enzymatic method}

The technique of Bull and Bookman (1977) was used as follows. Approximately $5 \mathrm{~g}$ mucosa was dissected and washed, as described above for the mechanical method. It was then cut into $20 \mathrm{~mm}^{2}$ sections in PBSA (supplemented with 100 units $/ \mathrm{ml}$ penicillin, $100 \mu \mathrm{g} / \mathrm{ml}$ streptomycin, and $40 \mu \mathrm{g} / \mathrm{ml}$ gentamicin) and incubated, with stirring, in $50 \mathrm{ml}$ $1 \mathrm{mM}$ DL-dithiothreitol (DL-DTT, Sigma) in supplemented PBSA for 15 minutes at room temperature to remove surface mucus. The tissue was then removed, washed in supplemented PBSA, and incubated with continuous stirring for 90 minutes in $50 \mathrm{ml} 0.75 \mathrm{mM}$ disodium EDTA (Sigma) in supplemented PBSA at $37^{\circ} \mathrm{C}$ to remove the surface epithelium. The tissue was then washed, preincubated in EMEM and stirred overnight at $37^{\circ} \mathrm{C}$ in EMEM (further supplemented with 100 units $/ \mathrm{ml}$ penicillin and $100 \mu \mathrm{g} / \mathrm{ml}$ streptomycin) containing 20 units $/ \mathrm{ml}$ purified collagenase (type VI, Sigma). All incubations were carried out in sealed, sterile $100 \mathrm{ml}$ polyethylene specimen containers. The resultant heterogeneous cell suspension was filtered through two nylon wool columns (see Mechanical method section) to disaggregate cell clumps, washed $\times 3$ in MEMS, and subjected to isokinetic gradient centrifugation as described below.

\section{PURIFICATION OF LAMINA PROPRIA}

\section{LYMPHOID CELLS}

\section{Siliconised glass bead columns}

Siliconised glass bead columns, constructed as described by Rudzik and Bienenstock (1974), were used to remove epithelial cell debris from the mechanically-separated lymphoid cell suspensions in some experiments. Each column comprised a $50 \mathrm{ml}$ plastic syringe barrel containing $2 \mathrm{~cm}$ (vertical height) of $1 \mathrm{~mm}$ diameter glass beads sandwiched between $1 \mathrm{~cm}$ (below) and $5 \mathrm{~cm}$ (above) of $3 \mathrm{~mm}$ diameter glass beads. A 16-mesh stainless steel grid at the base held the beads in place. All glass beads (Ballotini, Jencons Scientific) were siliconised and the columns were autoclaved before use. The flow rate through the columns was regulated to $1 \mathrm{ml} / \mathrm{min}$ using a $23 \mathrm{G} 1$ in hypodermic needle. Before use, each column was equilibrated with $25 \mathrm{ml}$ MEMS, which was then discarded. The cell suspension, reduced to $25 \mathrm{ml}$ in MEMS, was then run through the column, which was finally flushed with a further $25 \mathrm{ml}$ MEMS. Total, differential, and viability counts were carried out on the eluted cells.

\section{Isokinetic gradient centrifugation}

Isokinetic gradients of Ficoll (Ficoll 400, Pharmacia) in MEMS were generated in siliconised Pyrex tubes measuring $150 \mathrm{~mm} \times 20 \mathrm{~mm}$ diameter using a Buchler Multistaltic Pump. Each $40 \mathrm{ml}$ gradient varied linearly from $2.7 \% \mathrm{w} / \mathrm{v}$ Ficoll at the samplegradient interface $90 \mathrm{~mm}$ from the centre of revolution, to $5.5 \% \mathrm{w} / \mathrm{v}$ Ficoll at the gradient-cushion 
interface $205 \mathrm{~mm}$ from the centre of revolution, and was formed over a cushion of $30 \% \mathrm{w} / \mathrm{v}$ Ficoll.

Three millilitres of MEMS containing 10-20 $\times 10^{6}$ total cells was layered over each gradient. Gradients were centrifuged at $38 \mathrm{~g}$ for 14 minutes at $4^{\circ} \mathrm{C}$ in a MSE Coolspin centrifuge with an eight-place Universal swing-out head. Tubes were held in $50 \mathrm{ml}$ metal buckets fitted with $110 \mathrm{~mm} \times 25 \mathrm{~mm}$ diameter polypropylene sleeves. Acceleration was controlled so that maximum revolutions were reached after one minute and deceleration was at a similar rate.

After centrifugation, the $3 \mathrm{ml}$ starting sample was removed from the top of the gradient, followed by successive fractions measuring $5 \mathrm{ml}$ each. Total, differential, and viability counts were carried out on the cells recovered in all fractions and the fractions were then pooled as required. Recovered lymphoid cells were washed $\times 3$ in EMEM before inclusion in in vitro cytotoxicity assays.

\section{PROSTAGLANDIN EXTRACTION AND BIOASSAY}

The presence of prostaglandin (PG)-like activity in the cell suspension supernatants after mechanical homogenisation of mucosal tissue was determined using acidic lipid extracts of the supernatants. Two $1 \mathrm{ml}$ samples were removed from the $50 \mathrm{ml}$ supernatant medium. After the $\mathrm{pH}$ had been adjusted to $4 \cdot 0$, each sample was extracted twice with two volumes of diethyl ether, mixing thoroughly at each stage. Each ether extract was then evaporated to dryness under nitrogen, reconstituted with $1 \mathrm{ml}$ Kreb's buffered saline (KBS), and stored at $-20^{\circ} \mathrm{C}$ until assayed. Bioassay of PG-like activity was carried out using two gut baths in series, the first containing rat fundus strip and the second containing rat colon strip. The superfusate consisted of KBS containing $1.13 \mu \mathrm{M}$ methysergide, $0.36 \mu \mathrm{M}$ phentolamine, $7.7 \mu \mathrm{M}$ propranolol, $0.35 \mu \mathrm{M}$ atropine, and $0.50 \mu \mathrm{M}$ mepyramine as antagonists. The PG-like activity shown by each extract was quantified against calibration curves for the activity of the rat gut preparations to known amounts of purified $\mathrm{PGE}_{2}$ and $\mathrm{PGF}_{2} \alpha$ (Upjohn).

\section{CYTOTOXIC ASSAYS}

The antibody-dependent cellular cytotoxic (ADCC) potential of peripheral blood lymphocytes (PBL) and of isolated lamina propria lymphocytes was assayed in a ${ }^{51} \mathrm{Cr}$-release assay using Chang liver cells (CLC) as targets. CLC were grown in continuous culture as monolayers in $100 \mathrm{ml}$ glass bottles in EMEM (containing $10 \%$ FCS, which had not been heat-inactivated), and were harvested from confluent cultures by incubation with $0.6 \mathrm{mM}$ disodium EDTA in PBSA for 20 minutes at $37^{\circ} \mathrm{C}$. Harvested
CLC were washed $\times 3$ in EMEM and labelled with $100 \mu \mathrm{Ci}$ sodium chromate $\left({ }^{51} \mathrm{Cr}\right.$, Radiochemical Centre, Amersham) for one hour at $37^{\circ} \mathrm{C}$, washed $\times 3$ in EMEM, and adjusted to $10^{5} \mathrm{cells} / \mathrm{ml}$. AntiCLC antiserum was raised in rabbits by repeated intramuscular injections of $10^{7}$ CLC in Freund's complete adjuvant. Antiserum from a single rabbit was used in all the tests and was heat-inactivated at $56^{\circ} \mathrm{C}$ for 30 minutes before storage at $-70^{\circ} \mathrm{C}$.

PBL were separated from human heparinised whole venous blood obtained from healthy volunteer donors by sedimentation over Ficoll-Triosil.

ADCC assays were carried out in triplicate in round-bottomed $164 \mathrm{~mm} \times 10 \mathrm{~mm}$ diameter plastic tubes (Luckhams). To each experimental tube was added $100 \mu \mathrm{l}$ EMEM, $100 \mu \mathrm{l}$ labelled CLC $\left(10^{4}\right.$ cells), $100 \mu \mathrm{l}$ lymphocyte suspension $\left(2.5 \times 10^{5}\right.$ cells $)$, and $100 \mu \mathrm{l}$ anti-CLC antiserum $\left(10^{-3}\right.$ and $10^{-4}$ dilutions). Spontaneous cell-mediated cytotoxicity (SCMC) was assessed from tubes containing target and effector cells but without antiserum, and spontaneous isotope release (SR) from the target cells was determined in tubes containing target cells and EMEM only. Maximum release, assessed by detergent lysis of the target cells, was always $100 \%$. Tubes were capped and incubated at $37^{\circ} \mathrm{C}$ for 18 hours. After incubation, tubes were centrifuged at $150 \mathrm{~g}$ for five minutes; $200 \mu \mathrm{l}$ of each culture supernatant was withdrawn and counted with the residual supernatant plus cell pellet in a ICN Gamma Set 500 gamma counter. Percentage specific ${ }^{51} \mathrm{Cr}$ release from the target cells was calculated as follows:

$$
\begin{aligned}
& \%{ }^{51} \mathrm{Cr} \text { release }=\frac{\text { Supernatant } \mathrm{cpm} \times 2}{\text { Supernatant } \mathrm{cpm}+\text { Residual } \mathrm{cpm}} \\
& \% \text { Specific }{ }^{51} \mathrm{Cr} \text { release }=(\text { Experimental } \% \\
& \left.{ }^{51} \mathrm{Cr} \text { release-SR }\right)-\left(\mathrm{SCMC} \%{ }^{51} \mathrm{Cr}\right. \text { release- } \\
& \mathrm{SR}) .
\end{aligned}
$$

\section{Results}

MECHANICAL METHOD

The efficiency of the mechanical method, in terms of lamina propria lymphoid cell numbers recovered, is depicted in Table 1 . The mean number of lymphoid cells released per $\mathrm{g}$ of mucosal tissue was $3 \cdot 8 \times 10^{6} / \mathrm{g}$ (range, $1 \cdot 7-7 \cdot 3 \times 10^{6}$ ). Subsequent treatment of the cell suspension to disrupt and remove mucus reduced this mean value to $1.9 \times 10^{6} / \mathrm{g}$ (range, $\left.1.0-3.9 \times 10^{6}\right)$, a loss of lymphoid cells equivalent to $50 \%$ of the original number recovered. In addition, Table 1 shows that subsequent filtration of the suspension through nylon wool did not reduce the cell recovery. Indeed, in most experiments recovery was apparently improved using this procedure. This 
Table 1 Lymphoid cell yield after mechanical homogenisation of gut mucosal tissue

\begin{tabular}{|c|c|c|c|c|}
\hline \multirow[t]{2}{*}{ Patient } & \multicolumn{4}{|c|}{ Lymphoid cells $\times 10^{8} / \mathrm{g}$ mucosal tissue } \\
\hline & $\begin{array}{l}\text { After } \\
\text { homogenisation }\end{array}$ & $\begin{array}{l}\text { After } \\
\text { removal } \\
\text { of mucus }\end{array}$ & $\begin{array}{l}\text { After } \\
\text { nylon } \\
\text { column } \\
\text { filtration }\end{array}$ & $\begin{array}{l}\text { After } \\
\text { glass bead } \\
\text { column } \\
\text { purification }\end{array}$ \\
\hline $\begin{array}{l}\mathrm{CD} / 1 \\
\mathrm{CD} / 2 \\
\mathrm{CD} / 3 \\
\mathrm{CD} / 4 \\
\mathrm{AC} / 1 \\
\mathrm{AC} / 2 \\
\mathrm{AC} / 3 \\
\mathrm{AC} / 4 \\
\mathrm{AC} / 5 \\
\mathrm{AC} / 6 \\
\mathrm{AC} / 7 \\
\text { Mean } \pm \mathrm{SD}\end{array}$ & $\begin{array}{l}3 \cdot 1 \\
4 \cdot 0 \\
2 \cdot 5 \\
7 \cdot 3 \\
2 \cdot 6 \\
2 \cdot 2 \\
1 \cdot 7 \\
3 \cdot 6 \\
5 \cdot 6 \\
3 \cdot 5 \\
5 \cdot 7 \\
3 \cdot 8 \pm 1.7\end{array}$ & $\begin{array}{l}\overline{1.7} \\
1.6 \\
-1.6 \\
2.1 \\
1.3 \\
1.0 \\
3.0 \\
1.2 \\
3.9 \\
1.9 \pm 0.9\end{array}$ & $\begin{array}{l}2.0 \\
1 \cdot 7 \\
2 \cdot 2 \\
5.9 \\
1.6 \\
2 \cdot 1 \\
2 \cdot 1 \\
1.5 \\
3.4 \\
- \\
2.5 \pm 1.4\end{array}$ & $\begin{array}{l}- \\
- \\
- \\
- \\
- \\
- \\
- \\
\overline{0} \\
0.7 \\
1.6 \\
1.2 \pm 0.6\end{array}$ \\
\hline
\end{tabular}

CD: Crohn's disease.

AC: adenocarcinoma of the large bowel.

may be attributed to the disaggregation of cell clumps by the nylon wool, releasing further cells into single cell suspension.

At this stage, the lymphoid cell suspension was heavily contaminated with epithelial cells and cell debris and required purification before further investigation. Contamination with residual mucus frequently caused aggregation of cells within the suspension, causing problems with the subsequent purification procedures. Lymphoid cells were $85-95 \%$ viable at this stage as assessed by Trypan blue exclusion.

\section{GLASS BEAD COLUMN PURIFICATION}

Table 1 shows the results of two experiments in which the siliconised glass bead column method of purification was attempted. Prior removal of mucus from the suspension again caused a substantial loss $(45 \%)$ of originally-separated cells. In both experiments, passage through the glass bead columns resulted in further lymphoid cell loss. Mean cell numbers were reduced to $25 \%$ of original. Although the majority of cells eluted from the columns were of lymphocyte and plasma cell lineage (Table 2), there was a variable degree of monocyte/macrophage and polymorphonuclear cell contamination, and removal of epithelial cells was not complete. Lymphocyte Trypan blue viability was slightly improved after column treatment.

ISOKINETIC GRADIENT PURIFICATION

Because of the substantial loss of lymphoid cells experienced using the glass bead columns, all further gut lymphoid cell suspensions were purified using isokinetic gradients of Ficoll in MEMS. Figure 1 shows a typical distribution of gut lymphoid cells recovered in $5 \mathrm{ml}$ fractions from such a gradient. Preliminary experiments indicated that the optimum number of cells loaded on gradients of the dimensions used was between $10 \times 10^{6}$ and $20 \times 10^{6}$ total cells. Application of higher cell numbers overloaded the gradient and the separation became less efficient with more spread of cells from their modal populations into adjoining fractions. Differential counts of the types of cells recovered from each portion of the gradient are given in Table 2. For clarity, the fractions have been pooled into three groups labelled $\mathrm{A}, \mathrm{B}$, and $\mathrm{C}$. The $3 \mathrm{ml}$ starting sample contained only platelets after centrifugation and was discarded. The modal population of small lymphocytes was contained in the three $5 \mathrm{ml}$ fractions at the top of the gradient (A, Fig. 1). Table 2 shows that the lymphocytes recovered from these fractions were highly purified. Small lymphocytes and plasma cells were inevitably recovered in the same fractions but contamination with other cell types was minimal. Recovered lymphocytes showed $95-100 \%$ Trypan blue viability. The mid-portion of the gradient (B, Fig. 1, Table 2) contained very few cells, the majority of which were medium-sized lymphocytes with an increased content of cells of the monocyte/macrophage type. The fractions recovered from the gradient-cushion interface (C, Fig. 1, Table 2) contained a large number of non-viable and disrupted cells of variable morphology, aggregates of epithelial cells, cell debris, and a number of large lymphocytes.

A frequent observation when using the isokinetic gradients was that high yield of lymphocytes and

Table 2 Differential counts of gut mucosal cells purified either by glass bead column treatment or isokinetic gradient sedimentation

\begin{tabular}{|c|c|c|c|c|c|}
\hline & \multicolumn{4}{|l|}{$\%$ Total cells } & \multirow[b]{2}{*}{$\begin{array}{l}\text { Disrupted/ } \\
\text { unidentifiable }\end{array}$} \\
\hline & Lymphocytes & Plasma cells & $\begin{array}{l}\text { Monocytes/ } \\
\text { macrophages }\end{array}$ & Polymorphs & \\
\hline $\begin{array}{l}\text { Glass bead column } \\
\text { Isokinetic gradient }\end{array}$ & $68-82$ & $4-10$ & $5-11$ & $1-3$ & $5-7$ \\
\hline $\begin{array}{l}\mathbf{A} \\
\mathbf{B} \\
\mathbf{C}\end{array}$ & $\begin{array}{l}50-97 \\
95-97 \\
50\end{array}$ & $\begin{array}{l}3-50 \\
0 \\
0\end{array}$ & $\begin{array}{l}<1 \\
3-5 \\
2-5\end{array}$ & $\begin{array}{l}0 \\
<1 \\
<1\end{array}$ & $\begin{array}{l}0 \\
0 \\
45-50\end{array}$ \\
\hline
\end{tabular}




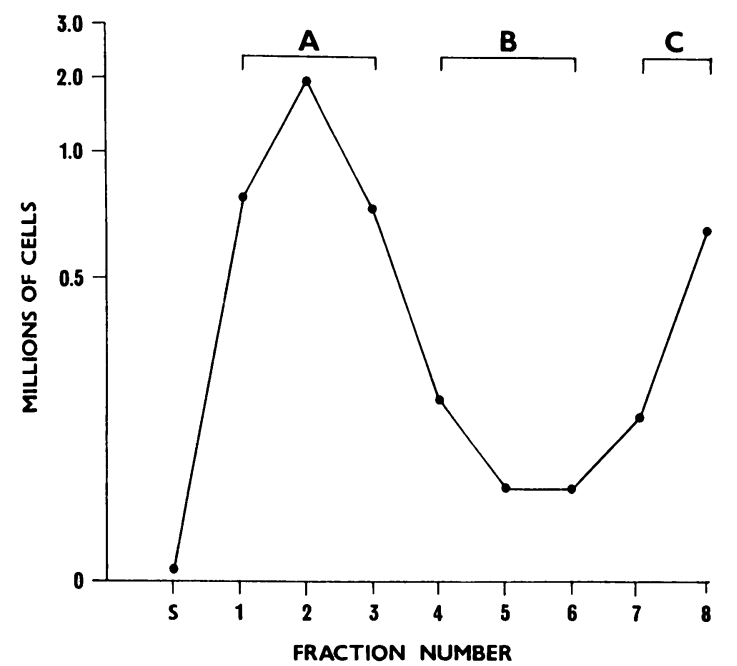

Fig. 1 Typical separation profile of large bowel lamina propria lymphoid cells after isokinetic gradient sedimentation. $S$ : sample volume $(3 \mathrm{ml})$. All successive fractions measured $5 \mathrm{ml}$. See Table 2 for differential cell counts within $A, B$, and $C$.

good separation from other cell types was dependent upon prior efficient removal of mucus from the sample suspension. Even small amounts of remnant mucus induced the formation of cell aggregates, streaming of cells within the gradient, and a consequent loss of separation efficiency. These problems were commonly encountered using suspensions derived from mechanically-separated samples but rarely so in the case of enzymatically-separated samples.

The high yield of lymphocytes minimally contaminated with other cell types prompted the continued use of this method. In all the ADCC assays reported below, therefore, the lamina propria lymphocytes used were those recovered from the top three $5 \mathrm{ml}$ fractions (A, Fig. 1) from isokinetic gradients.

\section{ADCC OF SEPARATED LAMINA PROPRIA LYMPHOCYTES \\ Mechanically-separated cells}

When the ADCC activity of mechanically-separated lamina propria cells was assessed, values consistently approaching zero were encountered. This prompted an investigation into the presence and nature of possible inhibitors of ADCC released during the separation procedure. Subsequently, it was found that when indomethacin $(15 \mu \mathrm{g} / \mathrm{ml})$ was added to the culture medium throughout the homogenisation procedure, the liberated lymphocytes showed significantly raised ADCC activity (Table 3).
Table 3 Effect of separation technique on subsequent ADCC of liberated mucosal lymphocytes

\begin{tabular}{llll}
\hline Patient & \multicolumn{2}{l}{$\%$} & \\
\cline { 2 - 3 } & $\begin{array}{l}\text { Mechanical } \\
\text { Medium }\end{array}$ & $\begin{array}{l}\text { Medium and } \\
\text { alone }\end{array}$ & \\
\hline indomethacin & \\
\hline CD/1 & 1.1 & 8.6 & - \\
CD/3 & 1.4 & - & - \\
CD/4 & 0.7 & 10.1 & - \\
AC/1 & 2.2 & -11.7 & 13.0 \\
AC/2 & 1.8 & -11.6 & - \\
AC/3 & 1.6 & $10.5 \pm 1.5$ & $-10.9 \pm 3.0$ \\
AC/5 & 1.6 & & \\
Mean \pm SD & $1.5 \pm 0.5$ & & \\
\hline
\end{tabular}

Addition of indomethacin to the separation medium also gave an appreciable increase in cell recovery (Table 4). Indomethacin, at the concentrations used, was not responsible per se for the observed increase in ADCC activity. This was demonstrated by the assessment of ADCC in PBL which had previously been incubated for two hours at room temperature in indomethacin of varying concentration (Table 5). It can be seen that concentrations in excess of those used during tissue homogenisation have little effect on ADCC capacity.

These results suggest that the addition of indomethacin suppressed the formation of an inhibitory factor released during tissue homogenisation. Subsequent extraction of acidic lipids from the supernatants of tissue homogenisations carried out in MEMS or MEMS with indomethacin, followed by

Table 4 Effect of separation technique on yield of mucosal lamina propria lymphoid cells

\begin{tabular}{llll}
\hline Patients & \multicolumn{3}{l}{ Lymphoid cells $\times 10^{\circ} / \mathrm{g}$ mucosal tissue } \\
\cline { 2 - 3 } & \multicolumn{2}{l}{ Mechanical method } & Enzymatic methods \\
\cline { 2 - 3 } & $\begin{array}{l}\text { Medium } \\
\text { alone }\end{array}$ & $\begin{array}{l}\text { Medium and } \\
\text { indomethacin }\end{array}$ & \\
\hline CD/1 & 3.1 & 7.5 & - \\
CD/4 & 7.3 & 8.9 & 32.8 \\
AC/1 & 2.6 & 4.2 & - \\
AC/2 & 2.2 & 3.7 & 6.5 \\
\hline
\end{tabular}

${ }^{*}$ Indomethacin concentration $=15 \mu \mathrm{g} / \mathrm{ml}$.

Table 5 Effect of indomethacin on ADCC of peripheral blood lymphocytes

\begin{tabular}{ll}
$\begin{array}{l}\text { Indomethacin concentration } \\
(\mu \mathrm{g} / \mathrm{ml})\end{array}$ & $\%$ Specific ${ }^{\mathrm{s1}} \mathrm{Cr}$ release $( \pm S D)$ \\
\hline 0 & $29 \cdot 4 \pm 5 \cdot 1$ \\
10 & $30 \cdot 3 \pm 1 \cdot 3$ \\
15 & $32 \cdot 1 \pm 4 \cdot 7$ \\
20 & $35 \cdot 6 \pm 5 \cdot 7$ \\
30 & $25 \cdot 8 \pm 2 \cdot 9$ \\
\hline
\end{tabular}

Results shown are the mean values from two experiments carried out in triplicate, using PBL from the same donor. 

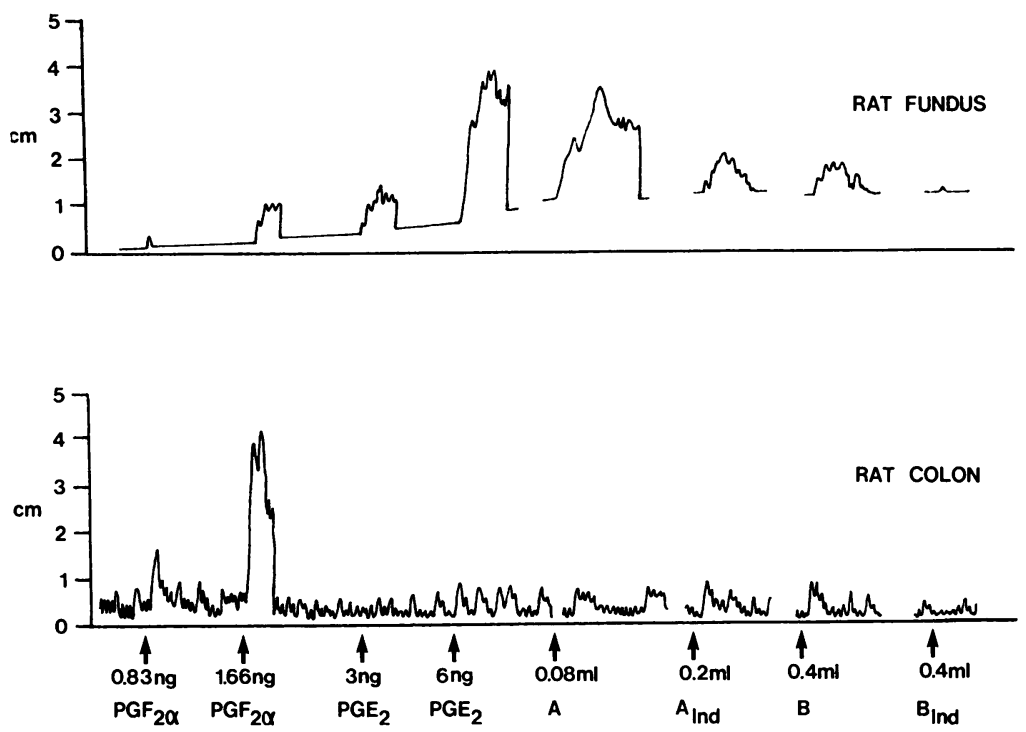

Fig. 2 Bioassay of prostaglandin-like activity in supernatant extracts from mechanically homogenised large bowel mucosa. A: extract of supernatant from mucosa (patient $A C / 2)$ homogenised in $M E M S$ alone. $A_{\text {Ind }}:$ extract of supernatant from mucosa (patient $A C / 2$ ) homogenised in $M E M S+$ indomethacin $(15 \mu \mathrm{g} / \mathrm{ml})$. B: extract of supernatant from mucosa (patient CD/1) homogenised in MEMS alone. $B_{\text {Ind }}$ : extract of supernatant from mucosa (patient $C D / 1)$ homogenised in MEMS + indomethacin $(15 \mu \mathrm{g} / \mathrm{ml})$.

bioassay of these extracts on rat fundus and colonic strip preparations revealed the possible nature of this inhibitory factor. Figure 2 demonstrates that the rat fundus preparation was more sensitive to $\mathrm{PGE}_{2}$ than to $\mathrm{PGF}_{2} \alpha$, and that the rat colon was preferentially sensitive to $\mathrm{PGF}_{2} \alpha$. Assay of the biological activity of extracts from the homogenate supernatants of two mechanical separation experiments clearly showed substantial amounts of PG-like activity, attributable to $\mathrm{PGE}_{2}$ alone. The activity in the extract from supernatant $A$ (patient $A C / 2$ ) was equivalent to $31 \mathrm{ngPGE} / \mathrm{ml}$ of homogenate supernatant. An adjacent section of mucosa homogenised in MEMS containing indomethacin yielded only $6.5 \mathrm{ng} \mathrm{PGE} / \mathrm{ml}$ of supernatant, an inhibition of PG synthesis equivalent to $71 \%$ when adjusted for tissue weight. In the second experiment depicted in Fig. 2, homogenisation of mucosa in MEMS yielded $6.3 \mathrm{ng} \mathrm{PGE} / \mathrm{ml}$ of supernatant $\mathrm{B}$ (patient $\mathrm{CD} / 1)$ and a barely detectable $0.75 \mathrm{ng} \mathrm{PGE}_{2} / \mathrm{ml}$ of supernatant was stimulated when adjacent mucosa was homogenised in MEMS with indomethacin, a weight-corrected inhibition of $90 \%$.

Table 6 Effect of prostaglandin $E_{2}$ on ADCC of peripheral blood lymphocytes

\begin{tabular}{lr}
\hline $\begin{array}{l}P G E_{2} \text { concentration } \\
(n g / m l)\end{array}$ & $\%$ Specific ${ }^{51}$ Cr release $( \pm S D)$ \\
\hline 0 & $30 \cdot 9 \pm 0 \cdot 4$ \\
10 & $24 \cdot 0 \pm 4 \cdot 7$ \\
20 & $4 \cdot 8 \pm 6 \cdot 2$ \\
\hline
\end{tabular}

Results shown are the mean values from two experiments carried out in triplicate using PBL from the same donor.
To investigate the possibility of $\mathrm{PGE}_{2}$ acting as an inhibitor of ADCC, PBL were incubated in various concentrations of purified $\mathrm{PGE}_{2}$ for two hours at room temperature before assaying their ADCC potential. The results (Table 6) clearly show that $\mathrm{PGE}_{2}$ can, indeed, exert a marked effect on lymphocyte ADCC activity.

\section{Enzymatically-separated cells}

Because of the PG-stimulating effect of mechanical homogenisation of mucosal tissue, described above, an alternative technique employing enzymes to release the lamina propria lymphoid cells was attempted. Column chromatography-purified collagenase (type VI, Sigma) described as 'essentially protease-free' was used in the method described by Bull and Bookman (1977) to minimise possible effects on lymphocyte surface membrane receptors.

In two experiments, the efficiencies of mechanical and enzymatic methods were determined using identical tissue samples for each method (Table 4). Treatment with collagenase yielded significantly more lymphoid cells than tissue homogenisation in medium alone, or even in medium containing indomethacin. Moreover, the cell suspensions obtained from collagenase-digested mucosal tissue contained no detectable mucus, indicating the efficient mucolytic action of DTT. Liberated lymphoid cells exhibited $95-100 \%$ Trypan blue viability.

After isokinetic gradient purification, the enzymatically liberated lymphocytes retained ADCC activity (Table 3 ) comparable with that measured in lymphocytes liberated mechanically in medium containing indomethacin. 


\section{Discussion}

Several attempts to separate and characterise gut mucosal lymphoid cells have been described, both in animals (Rudzik and Bienenstock, 1974; ArnaudBattandier et al., 1978) and in man (Breucha et al., 1974a,b; Mavligit et al., 1974; Clancy, 1976; Bull and Bookman, 1977; Crofton et al., 1978; Goodacre et al., 1979). In the only reported study comparable with the present investigation (homogenisation of large bowel mucosa), Goodacre et al. (1979) demonstrated a mean recovery of $12.7 \times 10^{6}$ lymphoid cells per gram of mucosa. This is considerably higher than the recovery experienced by ourselves $\left(3.8 \times 10^{6}\right.$ lymphoid cells per gram of mucosa) using a similar method. As in the present study, however, Goodacre et al. (1979) report a considerable range of recoveries $\left(2 \cdot 8-38 \times 10^{6} / \mathrm{g}\right.$; cf. present study, $1 \cdot 7-$ $7 \cdot 3 \times 10^{6} / \mathrm{g}$ ). There are three possible reasons for this wide range of cell recoveries using the mechanical method. Firstly, the extent of lymphoid cell infiltration is variable between mucosal samples. Secondly, although the characteristics of the homogenisation procedure were standardised as far as possible, the effectiveness of homogenisation remained variableindeed, such variability is inherent in the method. Finally, and most importantly, the mucus content differed between tissues, causing cell aggregation and trapping to a variable extent. The technique described by Clancy (1976) for removal of mucus from cell suspensions, in our hands accounted for a loss of $50 \%$ of the original lymphoid cells separated. It is likely that such cell loss would be greater from separations using large intestine-for example, this study-with a high mucus content, than from separations using small intestine-for example, Clancy, 1976-having a relatively low mucus content.

Glass bead column purification of the liberated cells in the present study accounted for a further $30 \%$ loss of cells. It is interesting that, in those experiments of Goodacre et al. (1979) where cell suspensions were subsequently treated using glass bead columns, the final cell recovery was, on average, $20 \%$ below the recovery from experiments in which columns were not used. Thus, although siliconised glass bead columns are relatively efficient at removing epithelial cell debris, they also remove considerable numbers of lymphoid cells. Subsequent experiments (unpublished) using PBL on glass bead columns indicated that most of this cell loss may be attributed to trapping by cell aggregates rather than to cell adherence to the column.

In comparison, isokinetic gradient purification was highly efficient, both in terms of cell recovery and of lymphoid cell purity. Thus, it was possible to recover $95-100 \%$ of the mononuclear cells layered onto each gradient. Approximately $70 \%$ of these cells were recovered as the modal population of small lymphocytes and plasma cells. The gradients were centrifuged at a centrifugal force $(38 g)$ much less than that $(97 g)$ routinely used by Pretlow and his co-workers in their numerous reports of cell separation by isokinetic gradient sedimentation (for example, Pretlow et al., 1971, 1973, 1977). We have found that, although the use of higher centrifugal forces applied to the gradients gives improved separation of cell types, when applied to mucosal cell preparations, decreased yields are experienced. This may be explained by the presence, in mucosal cell preparations, of cell doublets and triplets which, when applied to an isokinetic gradient, act as cells of correspondingly increased diameter and are forced towards the gradient-cushion interface. However, it has been shown that separations of cell suspensions with a greater heterogeneity of cell types-for example, from tumours-certainly require the application of higher centrifugal forces to produce lymphocyte populations of satisfactory purity (Pretlow et al., 1977). Other workers (Bull and Bookman, 1977; Arnaud-Battandier et al., 1978) have purified the gut lymphoid cells by sedimentation over discontinuous Ficoll-Hypaque gradients. In our experience, lymphocyte recovery and purity were always less after discontinuous gradient sedimentation than when isokinetic gradients were used to purify the cell suspension.

The dramatic effects on subsequent cell recovery and lymphocyte cytotoxic capacity of adding indomethacin to the culture medium throughout mechanical separation experiments suggested that prostaglandins were implicated in the suppression of lymphocyte functional capacity. Subsequent bioassay of homogenate supernatants clearly showed that substantial $\mathrm{PGE}_{2}$ synthesis was taking place during the homogenisation procedure. The addition of indomethacin, a potent PG synthetase inhibitor (Vane, 1971), greatly inhibited this synthesis. It appears that the homogenisation procedure causes disruption of cell membranes, releasing the arachidonic acid precursors of PG synthesis. E-series PGs have been shown to inhibit many human lymphocyte functions in vitro. Thus, Cook et al. (1978) have shown inhibition of the lymphocyte anamnestic antibody response; Lomnitzer et al. (1976) demonstrated PGE inhibition of leucocyte inhibitory factor production by PHA-stimulated lymphocytes; Smith et al. $(1971 \mathrm{a}, \mathrm{b})$ report that the raised levels of lymphocyte cyclic AMP induced by PGE have marked inhibitory effects on $\left[{ }^{3} \mathrm{H}\right]$ thymidine incorporation into PHA-stimulated lymphocytes; Goodwin et al. $(1977 \mathrm{a}, \mathrm{b})$ have shown inhibition of 
mitogen stimulation by low concentrations of $\mathrm{PGE}_{1}$ and $\mathrm{PGE}_{2}$ and have recently postulated a specific receptor for PGE on human lymphocytes (Goodwin et al., 1979), which may account for these potent and wide-ranging effects. With relevance to the present study, Droller et al. $(1978 \mathrm{a}, \mathrm{b})$ have shown that $\mathrm{PGE}_{2}$, in concentrations as low as $10^{-8} \mathrm{M}$, have, in their system, an inhibitory effect on lymphocyte ADCC which they attribute to PG-induced increases in lymphocyte intracellular cyclic AMP. We have demonstrated the presence in mucosal tissue homogenate supernatants of $\mathrm{PGE}_{2}$ concentrations of $6.3 \mathrm{ng} / \mathrm{ml}$ and $31 \mathrm{ng} / \mathrm{ml}$ in two experiments, and have shown that, in our system, significant suppression of ADCC in PBL could be achieved by preincubation of the effector cells in $\mathrm{PGE}_{2}$ concentrations at least as low as $10 \mathrm{ng} / \mathrm{ml}\left(2 \cdot 8 \times 10^{-8} \mathrm{M}\right)$.

The stimulation of PGE synthesis induced by membrane disruption in mechanical separation procedures will, presumably, vary, depending upon the degree of cellular breakdown. However, it is unlikely that all PG synthesis can be avoided during tissue homogenisation as Piper and Vane (1971) have shown that even mild mechanical stimuli can induce PG synthesis. Subsequent assessment of lymphocyte responses must, therefore, take account of this. Goodacre et al. (1979) report a delayed and reduced mitogenic response of gut lamina propria lymphocytes to PHA, when compared with PBL. The lymphocytes in their study were released by a mechanical method and it is possible that consequent PG synthesis and raised lymphocyte cyclic AMP levels caused suppression of the lymphocyte mitogenic response, a mechanism which is well documented (Smith et al., 1971a,b; Goodwin et al., 1977a,b). The weak stimulatory effect of low concentrations of cyclic AMP on the spontaneous rate of DNA synthesis in mitogen unstimulated lymphocytes reported by Smith et al. (1971b) may explain the variability in this parameter found by Clancy (1976) in mechanically-separated mucosal lymphocytes. The effects of indomethacin on cell recovery after mucosal homogenisation observed in the present study are difficult to explain. Subjectively, cell suspensions derived from tissue homogenisation in medium with indomethacin contained less mucus. Raised cell recovery may, therefore, be due to a possible mucolytic action of indomethacin resulting in less cell aggregation and trapping.

The present study provides the first direct evidence for the existence of cytotoxic effector cells in the human large bowel lamina propria. This conflicts with previous reports revealing no evidence for the existence of $\mathrm{K}$ cells in the colonic mucosa (Bookman et al., 1977; Bull and Bookman, 1977), but substantiates the work of Strickland et al. (1975) who reported histological evidence for the presence of Fc-receptor bearing cells in the colonic lamina propria of normal individuals and of patients with Crohn's disease. The importance of such cells as possible mediators of cytotoxic reactions to colonic epithelial cells in Crohn's disease has been reported by Stobo et al. (1976).

The lymphoid cell yield per gram of mucosal tissue was greatly increased by the use of an enzymatic method of tissue disaggregation. In the two experiments reported, cell recovery was $32.8 \times 10^{6} / \mathrm{g}$ and $6.5 \times 10^{8} / \mathrm{g}$, which compares with $15.0 \times 10^{6} / \mathrm{g}$ described by Bull and Bookman (1977) who used an identical method (if we assume that $1 \mathrm{~cm}^{2}$ of mucosa weighs approximately $0.5 \mathrm{~g}$ ). The enzymaticallyliberated lymphocytes, after purification on isokinetic gradients, showed similar ADCC activity to lymphocytes liberated mechanically in medium containing indomethacin. This further confirms the inhibitory effect of $\mathrm{PGE}_{2}$ synthesised during mechanical homogenisation.

All techniques designed to liberate lymphoid cells from a complex tissue such as the gut must represent a compromise. However, we have shown that, as a method liberating high yields of lymphocytes retaining intact membrane receptors and the capacity for ADCC, enzymatic digestion of the gut mucosa, as described, demonstrates distinct advantages over methods employing mechanical homogenisation of the tissue. Further characterisation of the cytotoxic capacity of lamina propria lymphocytes is therefore in progress using this technique, in conjunction with isokinetic gradient sedimentation to purify the liberated cells.

We wish to thank the surgical staffs of the Royal United Hospital and St Martin's Hospital and the members of the Haematology Laboratory for their assistance. We are grateful to Miss Kate Harris for technical assistance, to $\mathrm{Dr} K$. I. Williams and Mr Kamal El Tahir for helpful advice and discussion; and to Miss Rachel Humphreys for typing the manuscript. The work was supported by the Wessex Regional Health Authority.

\section{References}

Arnaud-Battandier, F., Bundy, B. M., O'Neill, M., Bienenstock, J., and Nelson, D. L. (1978). Cytotoxic activities of gut mucosal lymphoid cells in guinea-pigs. Journal of Immunology, 121, 1059-1065.

Auer, I. O., Buschmann, C., and Ziemer, E. (1978). Immune status in Crohn's disease. 2. Originally unimpaired cell mediated immunity in vitro. Gut, 19, 618-626.

Auer, I. O., Wechsler, W., Ziemer, E., Malchow, H., and Sommer, H. (1978). Immune status in Crohn's 
disease. 1. Leukocyte and lymphocyte sub-populations peripheral blood. Scandinavian Journal of Gastroenterology, 13, 561-571.

Bookman, M. A., Helms, R. A., and Bull, D. M. (1977). Isolated human intestinal mucosal lymphoid cells: Alterations in inflammatory bowel disease (IBD). (Abstract). Gastroenterology, 72, 1155.

Breucha, G., Rieber, E. P., and Riethmüller, G. (1974a). Characterization of lymphocytes isolated from human small intestine (Abstract). European Surgical Research, 6, suppl. 1, 38.

Breucha, G., Riethmüller, G., and Saal, J. (1974b). Gewinnung und Charakterisieurung von Lymphozyten aus gesunden und granulomatös veränderten humanen Dünndarmgeweben (Abstract). Zeitschrift fur Immunitätsforschung, 147, 333-334.

Bull, D. M., and Bookman, M. A. (1977). Isolation and functional characterization of human intestinal mucosal lymphoid cells. Journal of Clinical Investigation 59, 966-974.

Clancy, R. (1976). Isolation and kinetic characteristics of mucosal lymphocytes in Crohn's disease. Gastroenterology, 70, 177-180.

Cook, R. G., Stavitsky, A. B., and Harold, W. W. (1978). Regulation of the in vitro anamnestic antibody response by cyclic AMP. II. Antigen-dependent enhancement by exogenous prostaglandins of the $E$ series. Cellular Immunology, 40, 128-140.

Crofton, R. W., Cochrane, C., and McClelland, D. B. L. (1978). Preparation of lymphoid cells from small specimens of human gastrointestinal mucosa. Gut, 19, 898-906.

Droller, M. J., Perlmann, P., and Schneider, M. U. (1978a). Enhancement of natural and antibodydependent lymphocyte cytotoxicity by drugs which inhibit prostaglandin production by tumor target cells. Cellular Immunology, 39, 154-164.

Droller, M. J., Schneider, M. U., and Perlmann, P. (1978b). A possible role of prostaglandins in the inhibition of natural and antibody-dependent cellmediated cytotoxicity against tumor cells. Cellular Immunology, 39, 165-177.

Goodacre, R., Davidson, R., Singal, D., and Bienenstock, J. (1979). Morphologic and functional characteristics of human intestinal lymphoid cells isolated by a mechanical technique. Gastroenterology, 76, 300-308.

Goodwin, J. S., Bankhurst, A. D., and Messner, R. P. (1977a). Suppression of human T-cell mitogenesis by prostaglandin. Existence of a prostaglandin-producing suppressor cell. Journal of Experimental Medicine, 146, 1719-1734.

Goodwin, J. S., Messner, R. P., Bankhurst, A. D., Peake, G. T., Saiki, J. H., and Williams, R. C., Jr. (1977b). Prostaglandin-producing suppressor cells in Hodgkin's disease. New England Journal of Medicine, 297, 963-968.

Lomnitzer, R., Rabson, A. R., and Koornhof, H. J. (1976). The effects of cyclic AMP on leucocyte inhibitory factor (LIF) production and on the inhibition of leucocyte migration. Clinical and Experimental Immunology, 24, 42-48.

MacPherson, B. R., Albertini, R. J., and Beeken, W. L.
(1976). Immunological studies in patients with Crohn's disease. Gut, 17, 100-106.

Mavligit, G. M., Jubert, A. V., Gutterman, J. U., McBride, C. M., and Hersh, E. M. (1974). Immune reactivity of lymphoid tissues adjacent to carcinoma of the ascending colon. Surgery, Gynecology, and Obstetrics, 139, 409-412.

Meyers, S., Sachar, D. B., Taub, R. N., and Janowitz, H. D. (1976). Anergy to dinitrochlorobenzene and depression of T-lymphocytes in Crohn's disease and ulcerative colitis. Gut, 17, 911-915.

Meuwissen, S. G. M., Schellekens, P. T. A., Huismans, L., and Tytgat, G. N. (1975). Impaired anamnestic cellular immune response in patients with Crohn's disease. Gut, 16, 854-860.

Piper, P., and Vane, J. R. (1971). The release of prostaglandins from lung and other tissues. Annals of the New York Academy of Sciences, 180, 363-385.

Pretlow, T. P., Glover, G. L., and Pretlow, T. G., II. (1977). Purification of malignant cells and lymphocytes from a rat transplantable mucinous adenocarcinoma of the colon by isokinetic sedimentation in gradients of Ficoll. Journal of the National Cancer Institute, 59, 981-986.

Pretlow, T. G., II, Luberoff, D. E., Hamilton, L. J., Weinberger, P. C., Maddox, W. A., and Durant, J. R. (1973). Pathogenesis of Hodgkin's disease: separation and culture of different kinds of cells from Hodgkin's disease in a sterile isokinetic gradient of Ficoll in tissue culture medium. Cancer, 31, 1120-1126.

Pretlow, T. G., II, Pichichero, M. E., and Hyams, L. (1971). Separation of lymphocytes and macrophages from suspensions of guinea-pig peritonitis exudate cells using programmed gradient sedimentation. American Journal of Pathology, 63, 255-272.

Pretlow, T. G., II., Weir, E. E., and Zettergren, J. G. (1975). Problems connected with the separation of different kinds of cells. In International Review of Experimental Pathology, vol. 14, pp. 91-204. Edited by G. W. Richter and M. A. Epstein. Academic Press: New York.

Richens, E. R., Williams, M. J., Gough, K. R., and Ancill, R. J. (1974). Mixed lymphocyte reaction as a measure of immunological competence of lymphocytes from patients with Crohn's disease. Gut, 15, 24-28.

Rudzik, O., and Bienenstock, J. (1974). Isolation and characteristics of gut mucosal lymphocytes. Laboratory Investigation, 30, 260-266.

Smith, J. W., Steiner, A. L., Newburry, W. M., Jr., and Parker, C. W. (1971a). Cyclic adenosine 3', 5'-monophosphate in human lymphocytes. Alterations after phytohemagglutinin stimulation. Journal of Clinical Investigation, 50, 432-441.

Smith, J. W., Steiner, A. L., and Parker, C. W. (1971b). Human lymphocyte metabolism. Effects of cyclic and noncyclic nucleotides on stimulation by phytohemagglutinin. Journal of Clinical Investigation, 50, 442-448.

Stobo, J. D., Tomasi, T. B., Huizenga, K. A., Spencer, R. J., and Shorter, R. G. (1976). In vitro studies of inflammatory bowel disease. Surface receptors of the mononuclear cell required to lyse allogeneic colonic epithelial cells. Gastroenterology, 70, 171-176. 
Strickland, R. G., Husby, G., Black, W. C., and Williams, R. C., Jr. (1975). Peripheral blood and intestinal lymphocyte sub-populations in Crohn's disease. Gut, 16, 847-853.

Vane, J. R. (1971). Inhibition of prostaglandin synthesis as a mechanism of action for aspirin-like drugs. Nature (New Biology), 231, 232-235.

Verrier-Jones, J., Housley, J., Ashurst, P. M., and Hawkins, C. F. (1969). Development of delayed hypersensitivity to dinitrochlorobenzene in patients with Crohn's disease. Gut, 10, 52-56. 